PF 2020 (75/1): 109-121

https://doi.org/10.32798/pf.651

\author{
KATARZYNA DRÓŻDŻ-ŁUSZCZYK \\ Wydział Polonistyki \\ Uniwersytet Warszawski, Warszawa \\ e-mail:kdrozdz@uw.edu.pl \\ ORCID 0000-0002-7465-4379
}

\title{
JAK ZAPRACOWAĆ NA SZCZĘŚCIE? ROZWAŻANIA WOKÓŁ WŁAŚCIWOŚCI SEMATYCZNO-SKŁADNIOWYCH CZASOWNIKA ZAPRACOWAĆ
}

\author{
HOW TO EARN HAPPINESS? \\ SEMANTIC AND SYNTACTIC PROPERTIES OF THE VERB \\ ZAPRACOWAĆ
}

\begin{abstract}
The paper presents a syntactic analysis of the Polish verb zapracować ('to earn'). The point of departure is the observation that descriptions of verbal valency are often limited to formal analyses. Contrary to that, the author focuses on the semantic features of verbs, equally important in her opinion, and following this strategy, she confronts the valency structure of the lexemes zapracować and pracować. She proposes three syntactic positions for the verb zapracować, and presents semantic characteristics of the arguments filling these positions.
\end{abstract}

KEYWORDS: syntax, semantics, agens, object

SLOWA KLUCZOWE: składnia, semantyka, agens, obiekt

W badaniach składniowych niejednokrotnie zwracano uwagę, że właściwości konotacyjne, dotyczą zarówno formy jak i treści. Wskazywała na to Danuta Buttlerowa, w jednej z pierwszych dla języka polskiego prac poświęconych walencji wyrazów (Buttler 1976), podkreślała wielokrotnie Zofia Zaron w licznych artykułach (zob. zwłaszcza tom Zaron 2009), upominała się o odejście od wyłącznie powierzchniowego 
traktowania walencji Magdalena Danielewiczowa (Danielewiczowa 2018). Mimo to opisy składniowe nadal często skupiają się na zależnościach formalnych, traktując zależności dotyczące treści wyrażeń z mniejszą uwagą (o ile w ogóle poświęcają im miejsce).

W niniejszym szkicu chciałabym postawić pytania o pozycje składniowe czasownika zapracować i treści wypełniające owe pozycje. Zarysuję związane z nimi problemy, niekiedy wydobywając pewne właściwości w kontraście do czasownika pracować. Zestawienie to jest motywowane z jednej strony pochodnością słowotwórczą i wynikającym z niej podobieństwem formalnym, ujawniającym się także na poziomie otwierania pozycji składniowych. Wstępnie przyjmuję, że czasownik zapracować jak pracować przewiduje miejsce na mianownik, biernik (z przyimkiem $n a^{1}$ ) i - jak postaram się uargumentować - na narzędnik ${ }^{2}$ (por. ktoś pracowat na coś czymś vs. ktoś zapracowat na coś czymś).

W słownikach współczesnej polszczyzny poza czasownikiem zapracować odnotowany został również czasownik zapracowywać, który w USJP, ISJP i WSJP PAN uznaje się za formę niedokonaną zapracować. Chociaż w dalszej części skupiać się będę na formie dokonanej, którą uważam za prostszą semantycznie i dlatego wymagającą pierwszeństwa w opisie semantyczno-składniowym, chciałabym zwrócić uwagę na pewną kwestię. Otóż czasownik zapracowywać niezmiernie rzadko jest przez użytkowników polszczyzny wykorzystywany do tworzenia wypowiedzi. W NKJP jest zaledwie trzynaście poświadczeń dla zapracowywać3. Co więcej, nawet poszukiwania w tekstach internetowych nie przynoszą większej liczby potwierdzeń dla formy niedokonanej zapracowywać. Gdy mowa o tym, że ktoś robi coś, aby coś osiągnąć, używany jest czasownik pracować. Por.:

(1) Zapracował na swoje utrzymanie.

(2) Pracowal / pracuje na swoje utrzymanie.

(3) Zapracowywał / zapracowuje na swoje utrzymanie.

1 Przyimek jest istotną częścią jednostki. W tekstach pojawia się niekiedy zapracować / zapracowywać co. Zob. dalej przypis 3.

2 Pozycja narzędnika jako przewidziana na treści konotowane jest $\mathrm{w}$ tym przypadku kontrowersyjna. Chociaż w dalszej części postaram się przedstawić argumenty przemawiające za tym, że wynika ona z treści czasownika, to zdaję sobie sprawę, że rozstrzygnięcie ma charakter w pewnej mierze arbitralny. Wciąż jednak brakuje niezawodnych testów do weryfikacji konotowania (bądź niekonotowania) pozycji składniowych.

3 Wobec wielości form fleksyjnych czasowników, to niewiele. Większość poświadczeń z NKJP dotyczy zapracowywać się. Ponadto wyróżnia się jeden przykład, w którym pojawia się zapracowywać utworzone analogicznie do zajadać, oznaczające zajmowanie się pracą zamiast konfrontacji z prawdziwym problemem; por. Trzeba odkryć, co człowiek „zapracowuje”: nieudane matżeństwo, nieśmiałość w stosunku do innych ludzi czy brak przebojowości.

4 Forma pojawia się wyłącznie w hasłach opracowań o charakterze leksykograficznym, brak przykładów użyć w wypowiedziach. 
Na pytanie, czy przykłady takie jak ostatni z przywołanych wyżej różnią się od zdań z czasownikiem pracować, postaram się odpowiedzieć w dalszej części. Niemniej istnienie przywołanych zależności czyni omawianie czasownika zapracować $\mathrm{z}$ odwołaniem się do pracować rozwiązaniem w pełni dopuszczalnym.

Jak zostało już powiedziane, wstępnie przyjmuję, że czasownik zapracować otwiera pozycje składniowe: ktoś, na coś, czymś. W słownikach współczesnej polszczyzny pozycja agensa (ktoś) i druga pozycja wprowadzana po przyimku ( na coś), którą roboczo określić można jako obiektową, ujawniają się w przywołanych przykładach, por.:

(4) Uczeń zapracował na pochwałę. (USJP)

(5) Zapracować na utrzymanie. (USJP)

(6) Cały zespół zapracował na sukces. (WSJP)

(7) No to zapracuj na mieszkanie w Warszawie. (WSJP)

(8) A więc od dziś też będziesz musiał zapracować na kieszonkowe. (ISJP)

(9) Głuptas jesteś! Na szczęście też trzeba zapracować. (ISJP)

O ewentualnej pozycji czymś w opracowaniach leksykograficznych w zasadzie brak informacji. Pewne odstępstwo stanowi pod tym względem USJP, w którym omawianemu czasownikowi przypisywane są dwa znaczenia 5 . Pierwsze, ilustrowane przez przywołane wyżej przykłady, zapracować, czyli 'zdobyć (zdobywać), osiągnąć (osiągać) coś ciężką pracą; zarobić (zarabiać)'; drugie, używane ironicznie ${ }^{6}$, odnotowane $\mathrm{w}$ haśle słownikowym jako 'ponieść (ponosić) konsekwencje swojego postępowania', por.:

(10) Żył w osamotnieniu, na które sam sobie zapracował. (USJP)

Kształt definicji zapracować2 wskazuje - jakkolwiek nie wprost - na ewentualną trzecią pozycję otwieraną przez zapracować: zapracował czym (postępowaniem, por. przywołana wcześniej definicja). Dlatego w dalszych rozważaniach postawione zostanie pytanie nie tylko o ilość i jakość pozycji składniowych przy zapracować, lecz także o to, czy warto (należy) wyróżniać dwie jednostki języka oparte na kształcie zapracować: ktoś zapracował na coś oraz ktoś zapracował (sobie) na coś czymś?.

5 W USJP oznaczenia numeryczne w artykule hasłowym oznaczają dwa znaczenia. Przyjęłam tę terminologię za redaktorami, ponieważ jest zbieżna z moją intuicją dotyczącą dwu jednostek opartych na kształcie zapracować.

6 Kwalifikator zaczerpnięty z USJP.

7 Zob. o pozycjach składniowych czasownika pracować w Dróżdż-Łuszczyk 2011. Z kolei interpretację pojawiającego się często $\mathrm{w}$ wypowiedziach z czasownikiem zapracować zaimka sobie (ktoś zapracowat sobie na coś czymś) pomijam tu świadomie, jako niekonotowanego. Przegląd różnych użyć sobie można znaleźć w literaturze; np. Szupryczyńska 1996, Zaron 2009 (zwłaszcza rozdział siódmy Był sobie król... O polifunkcyjnym wyrazku SOBIE). 


\section{Pozycja ktoś}

Pozycja ktoś przy czasowniku zapracować jest przeznaczona dla agensa. W zasadzie trudno wskazać ograniczenia, które byłyby z nią związane. Może zostać wypełniona przez imiona własne, osobowe nazwy zawodów, zaimki osobowe; mogą to być zarówno nazwy osób dorosłych (które pracują zawodowo), jak i osób niedorosłych:

(11) Dzieci zapracowały na odpoczynek.

(12) Inżynier zapracował na sukces swojego projektu.

(13) Zespól siatkarek zapracował na zwycięstwo.

Ponieważ pewne właściwości semantyczne stają się wyraźniejsze, gdy są skontrastowane, zgodnie z wcześniejszymi zapowiedziami, przywołam w tym miejscu czasownik pracować, przy którym w pozycji agensa pojawiają się w zdaniach serio wyłącznie nazwy osób. Tymczasem przy zapracować możliwe są uzupełnienia o nazwy zwierząt, których działania postrzegamy jako warte nagrodzenia. Dlatego mówimy, że pies szukający przez kilka godzin nielegalnych towarów przewożonych przez granicę, zapracował na odpoczynek, natomiast konie startujące $\mathrm{w}$ wyścigu zapracowały na nagrodę $\mathrm{w}$ postaci ulubionych jabłek. Ta różnica $\mathrm{w}$ charakterystyce treści pojawiających się w pozycji ktoś pozwala na sformułowanie nieco dalej idących wniosków. Otóż w pozycji przeznaczonej dla agensa przy czasowniku zapracować musi wystąpić ktoś, kto coś robi, ale - w przeciwieństwie do pozycji ktoś realizowanej przy czasowniku pracować - nie zostaje mu przypisana celowość działań oraz chęć dokonania zmiany. Różnica staje się łatwiej uchwytna, kiedy przyjrzeć się kolejnej pozycji składniowej, czyli na coś.

\section{Pozycja na coś}

Przy czasowniku zapracować w pozycji na coś wystąpić mogą rzeczowniki nazywające obiekty materialne (por. zapracował na dom, samochód, na nowe ciuchy), jak i rzeczowniki nazywające obiekty abstrakcyjne (por. zapracował na uznanie, na sukces, na zwycięstwo, na kręgosłup moralny ${ }^{8}$ ). Bez względu jednak na to, jakiego typu rzeczownik wystąpi w pozycji na coś, faktycznie odsyłać on będzie nie do przedmiotów, lecz do działań, do zmiany pewnego stanu rzeczy.

Kiedy mówimy:

(14) Kowalski pracuje na dom.

8 Ostatnie z przywołanych uzupełnień - aczkolwiek w mojej ocenie niefortunne - podaję za NKJP, por.: Judo dla Grabowskiego jest sportem czystych regut, a ponieważ na kregostup moralny zapracowat sobie w sporcie, tym łatwiej przestrzegać mu reguł w życiu. 
(15) Jasiek pracuje na dobry wynik w maratonie.

- stwierdzamy, że ktoś wie, że robi coś, aby coś osiągnąć (odpowiednio - żeby mieć dom, żeby osiągnąć satysfakcjonujący wynik w zawodach) ${ }^{9}$. Realizacje, które pojawiają się przy czasowniku pracować w pozycji na coś, wskazują na cel podejmowanej pracy:

pracować na autorytet / wyjazd ( $\approx$ pracować, aby zdobyć autorytet, aby zdobyć środki na wyjazd), pracować na siebie i brata ( $\approx$ pracować, aby utrzymać siebie i brata) etc ${ }^{10}$.

Dla wszystkich wymienionych połączeń pozycja na coś odsyła do celu działania, zarazem wspólna jest dla nich przypisywana agensowi chęć zmiany.

Odmiennie jest w przypadku pozycji na coś przy zapracować. W tym przypadku pozycja na coś nie wprowadza informacji o celu działań. Co warte podkreślenia, istnieje możliwość łączliwości obu czasowników (tj. zapracować i pracować) z tymi samymi wyrażeniami, np. zapracował na dom, na dobry wynik, na autorytet, na wyjazd, na siebie $i$ brata, jednak inne informacje są wówczas przekazywane.

Zanim spróbuję odpowiedzieć na pytanie o to, na czym polega różnica pomiędzy pracowaniem na autorytet a zapracowaniem na autorytet, chciałabym przywołać kilka przykładów, które zilustrują, jak trudno jest oddzielić to, co wynika ze znaczenia wyrażeń językowych, od tego, co wynika z niezależnej od języka wiedzy o świecie. Por.:

(16) Na „Nike” zapracowała pisząc Biegunów.

(17) Na „Nike” zapracował ostatnim tomem opowiadań.

Pierwszy z przykładów ilustruje sytuację, w której poprzez podanie tytułu powieści może zostać rozpoznany (nieobecny formalnie) agens. Nasuwająca się interpretacja, że Olga Tokarczuk otrzymała nagrodę za Biegunów, to jednak konsekwencja posiadania pewnej wiedzy o świecie, konsekwencja, która nie wynika ze znaczenia wyrażeń. Dlatego uzasadnione wydaje się uznanie, że czasownik zapracować nie rozstrzyga jednoznacznie, że cel został osiągnięty. Oba przytoczone wyżej przykłady można poprawnie zinterpretować jako wypowiedzi opisujące sytuację, w której decyzje o tym, komu przyznać „Nike”, jeszcze nie zapadły. Dowodzi tego brak sprzeczności w wypowiedziach jak poniższe:

(18) Ostatnim tomem opowiadań zapracował (nawet) na „Nike”, ale nagrody tej nie dostał.

9 Więcej o czasowniku pracować zob. w przywoływanym już artykule Dróżdż-Łuszczyk 2011.

10 Cel w przypadku czasownika pracować mógłby być wskazywany również poprzez połączenia z przysłówkiem, jak pracować zarobkowo ( $\approx$ pracować, aby zarobić). Brak seryjności i możliwego wprowadzenia innego przysłówka zamiast zarobkowo wskazuje, że połączenie takie trafniej byłoby traktować jako zleksykalizowane. 
(19) Zapracował na wyjazd, ale nie wyjechał.

Potwierdza to również nieredundantne:

(20) Zapracował na wyjazd i wyjechał.

Por. także:

(21) Zapracował na awans, jednak go nie dostał.

- które warto zestawić z (ponownie) nieredundantnym:

(22) Zapracował na awans i dostał awans.

Czasownik zapracować nie przesądza osiągnięcia zmiany pewnego stanu rzeczy wskazanego przez wyrażenie pojawiające się w pozycji na cośl1 . Co więcej, o ile czasownik pracować wiąże się z chęcią agensa, by zmian dokonywać, o tyle zapracować takiego komponentu nie zawiera - być może wyklucza to związany z omawianym czasownikiem aspekt dokonany. W tej sytuacji pozycja na coś nie powinna być interpretowana jako pozycja wskazująca na cel działań ${ }^{12}$, lecz jako ukazująca pewien skutek. Zaznaczyć należy od razu, że skutek działań nie jest bynajmniej wskazany bezpośrednio przez rzeczownik wymieniony w bierniku; skutkiem jest to, że agens może już osiągnąć to, co wskazane w bierniku. Innymi słowy, stwierdzenie, że ktoś zapracował na nagrodę, dom, awans, nie oznacza, że dostał nagrodę, ma dom, uzyskał awans, lecz jedynie, że przez osobę wskazaną w pozycji agensa zostały spełnione warunki wystarczające, by mogła ona dostać nagrodę, mieć dom, uzyskać awans. O ile pracuje się na coś, by to coś mieć, o tyle można na coś zapracować, bynajmniej na to nie pracując, oraz mimo że się zapracowało, wcale tego nie miećl ${ }^{3}$. W ten sposób możliwe staje się wskazanie różnic pomiędzy przywołanym wcześniej przykładem (2) oraz (3) z czasownikami pracować oraz zapracowywać. Przypomnijmy je:

(2) Pracował / pracuje na swoje utrzymanie.

(3) Zapracowywał / zapracowuje na swoje utrzymanie.

11 Uwaga dotyczy zdań twierdzących. Inną interpretację należy przyjąć w przypadku pytań. Por. przykładowo: Czym zapracowat sobie na opinię zakały? oraz Jak zapracował na apartament $w$ centrum miasta?! W obu tych wypowiedziach jest przesądzona jedna z możliwości (odpowiednio, że jest zakałą, że ma apartament), druga - że nie jest zakałą, nie ma apartamentu - zostaje wykluczona. Jest to właściwość wypowiedzi pytajnych.

12 Jak ma to miejsce wobec czasownika pracować.

13 Pozornie inne zdają się kolokacje, w których w pozycji biernikowej pojawiają się rzeczowniki typu miano, przydomek, ksywka, por.: W polityce wewnętrznej Harald solidnie zapracowat na swój przydomek - Srogi. W trakcie awantury o media zapracował (sobie) na miano ojca najbardziej kontrowersyjnych przepisów. Jednak i takie konteksty nie przesądzają, czy tylko ze znaczenia - nie z wiedzy o świecie - wynika to, że ktoś ma przydomek Srogi, albo że określany jest jako ojciec kontrowersyjnych przepisów etc. 
W zdaniu (zdaniach) z czasownikiem pracować mowa jest o działaniu celowym, którego agens jest świadom. W przykładzie (przykładach) z czasownikiem zapracowywać agens nie musi mieć świadomości, że jego działania są rozumiane jako rekompensujące jego utrzymanie. Nie robi czegoś po to, by mieć zapewnione utrzymanie.

W tym miejscu warto zasygnalizować pewną kwestię, która regularnie pojawia się w definicjach słownikowych przy czasowniku zapracować. Chodzi mianowicie o to, czy faktycznie zapracowanie na coś związane jest $\mathrm{z}$ ciężką pracą. Taka informacja odnotowana została w USJP, por. zapracować 1. 'zdobyć (zdobywać), osiągnąć (osiągać) coś ciężką pracą; zarobić (zarabiać)'; odnalazła się również w WSJP, gdzie zapracować to 'zdobyć coś, ciężko pracując' oraz w ISJP 'Jeśli zapracowaliśmy na coś, to ciężko pracując, osiągnęliśmy to lub zasłużyliśmy na to. Na tym etapie charakterystyki czasownika zapracować należy raczej przyjąć, że ciężka praca bynajmniej nie jest konieczna, by na coś zapracować, niezbędna jest za to dostateczna (wystarczająca) ilość pracy czy innych działań, by warunek konieczny do tego, by móc osiągnąc to, co wskazane w pozycji na coś, został spełniony. Dlatego wypowiedzi jak:

(23) Zapracował na dom ciężką pracą.

(24) Na sukces zapracowali ciężką pracą i godnym podziwu uporem.

- uważam nie za redundantne, lecz co najwyżej za nieporadne stylistycznie z powodu powtarzającej się cząstki prac $^{-14}$. Niewykluczone, że wpisywanie w definicje czasownika zapracować elementu, który odsyła do ciężkiej pracy, spowodowane jest łączeniem znaczenia omawianego czasownika z zapracować się ${ }^{15}$, a zwłaszcza ze zleksykalizowanym zapracować się na śmierć, które dobitnie wskazuje, że można pracować za ciężko i za dużo.

Z przywoływanym w słownikach elementem znaczenia, który wskazuje, że $z a$ pracować oznacza ciężką pracę, wiąże się jedna jeszcze - również sygnalizowana już - kwestia. Dotychczas jako uzupełnienia w pozycji na coś przywoływane były treści, które odsyłały do tego, co dobre lub uważane za pożądane społecznie, bo tylko takie zdają się zasługiwać na podejmowanie trudu (definicyjnej ciężkiej pracy). Jednak - jak wskazali na to redaktorzy USJP - pozycja ta może być również wypełniana przez wyrażenia, które wskazują na to, co oceniane jest jako złe, niewłaściwe, niepożądane. W przywoływanym już przykładzie z USJP pozycja

14 Obecność tego typu zdań w korpusie NKJP świadczy, że nie jest to wyłącznie moja intuicja, lecz również innych użytkowników polszczyzny.

15 Warto dodać, że wbrew formie czasownik zapracować się semantycznie związany jest z pracować, a nie zapracować. Miejsce zapracować się widziałabym wśród czasowników, które Wróbel charakteryzował jako formacje utworzone $z a-\ldots$ się i oznaczające całkowite zaabsorbowanie subiektu akcją podstawową (zob. GWJP s. 550, t. 2). 
na coś została wypełniona przez osamotnienie. Ale nie jest to jednostkowy przykład pojawiania się w tej pozycji treści negatywnych, ponieważ równie możliwe są uzupełnienia: zapracował na ostracyzm społeczeństwa, na pomijanie przez kolegów, na pozbawienie tytułu mistrza olimpijskiego etc. Redaktorzy USJP z tym odmiennym sposobem wypełniania pozycji związali osobne znaczenie czasownika zapracować i przypisali mu inne właściwości pragmatyczne ${ }^{16}$.

Sądzę, że rozróżnienie dwu znaczeń zapracować można motywować inaczej niż względami pragmatyki, mianowicie treściami, które pojawiają się w pozycji na $\cos ^{17}$. Gdy rozmówcy sięgają po czasownik zapracować2, który w pozycji obiektu zdarzeniowego dopuszcza wystąpienie tego, co postrzegane jest jako niekorzystne dla agensa, mówią o sytuacji, w której skutek już jest zauważalny. Gdy mowa o tym, że ktoś zapracował na dom, stwierdzone zostaje, iż pracował tyle, że mógł kupić dom (jednak nie jest powiedziane, że ostatecznie kupił). Jeśli jednak mowa o tym, że zapracował (sobie) na pozbawienie tytułu mistrza, to oznacza, że zrobił tyle pewnych (złych) rzeczy, że został pozbawiony tytułu ${ }^{18}$. To z kolei pozwala wysnuć wniosek, że właściwością zapracować2 jest także to, że skutki oceniane jako złe, dotyczą agensa. Jest to widoczne w przykładzie przywoływanym w USJP (zob. przytoczony wcześniej przykład 10.) i pozwala odróżnić informację, że ktoś zapracował na pozbawienie tytułu mistrzowskiego siebie (zapracować2), od informacji, że ktoś zapracował na pozbawienie tytułu mistrzowskiego swojego przeciwnika (zapracować1).

\section{Pozycja czymś}

Przy czasowniku pracować pozycja czymś, wprowadzająca narzędzie, nie zawsze pojawia się na powierzchni, jest jednak konotowana ${ }^{19}$. Jak się zdaje, ze względu na złożoność lub specyfikę narzędzia jest to pozycja najrzadziej realizowana. Z jednej strony nietrudno odnaleźć w tekstach kolokacje wskazujące, że ktoś pracuje wiertarka, albo że pracuje głosem, $\mathrm{z}$ drugiej strony w przypadku osoby pracującej nad projektem, dysertacją, czy książką, narzędzie nie jest określane ze względu na jego złożoność. Niemniej w odniesieniu do czasownika pracować pozycja

16 Użycie ironiczne. Jednak należy pamiętać, że ironia jest nie tyle nacechowaniem leksemu, co wynika z użycia go w wypowiedzi, powiązania go z innymi wyrażeniami i środkami prozodycznymi.

17 Zmiana w sposobie wypełniania pozycji na coś pociąga za sobą zmianę w sposobie wypełniania pozycji agensa ktoś. W wypowiedziach serio przy zapracować2 nie pojawiają się w pozycji ktoś nazwy zwierząt.

18 Istnieje też druga możliwość: ktoś mógł nie zrobić nic, by przeciwdziałać zmianie stanu rzeczy na niekorzystny dla siebie.

19 Więcej na ten temat w Dróżdż-Łuszczyk 2011. Tam też dyskusja, dlaczego pozycja narzędzia powinna być uważana za konotowaną. 
narzędzia jest wskazywana jako wynikająca ze znaczenia. Tymczasem w odniesieniu do czasownika zapracować istnieją wątpliwości, czy jest to pozycja /1/ konotowana /2/ przeznaczona na narzędzie. Zaciemniają wgląd w tę pozycję składniową pozornie konkurujące z narzędnikiem imiesłowowe równoważniki zdań jak:

(25) Mateusz na swoją pozycję zapracował przez lata, przede wszystkim zdobywając złoto olimpijskie.

(26) Carleton Fiorina zapracowała na swój sukces, kierując przez wiele lat największym działem znanej firmy komputerowej.

(27) Na rzęsiste oklaski na finał zapracował, grywając niewielkie, nie zawsze wdzięczne, ale zawsze dobrze zrobione epizody w macierzystym Narodowym.

Imiesłowowe równoważniki zdań nie są konotowane. Poza tym wydają się występować w pozycji czymś, dlatego powierzchniowe realizacje tego typu nasuwają $\mathrm{z}$ jednej strony przypuszczenie, że również pozycja czymś jest niekonotowana, z drugiej zaś, że treści wskazywane w imiesłowowym równoważniku zdania jak i wprowadzane pozycją czymś, zdają sprawę z relacji przyczynowo-skutkowych ${ }^{20}$. Tymczasem oba wnioski są nieuzasadnione. Przede wszystkim, imiesłowowe równoważniki zdań nie wykluczają wystąpienia pozycji czymś, raczej zdają się doprecyzowywać treści z niezrealizowanego (bo oczywistego ze względu na wnoszone treści) narzędnika. Por.:

(28) Mateusz na swoją pozycję zapracował przez lata wynikami w zawodach żeglarskich, przede wszystkim zdobywając złoto olimpijskie.

Szukając odpowiedzi na pytanie, czy pozycja czymś, jest konotowana i czy wskazuje na narzędzie, czy na przyczynę, warto przyjrzeć się kilku przykładom:

(29) Na przyjazny gest Malediwów zapracował talentem dyplomatycznym.

(30) Na swoje osiągnięcia zapracowała talentem i ciężką, sumienną pracą.

(31) Na stypendia burmistrza uczniowie zapracowali osiągnięciami w nauce i sporcie.

(32) Na pominięcie w dyskusji zapracował sobie lekceważeniem problemu.

Zgodnie z jednym z testów przywołanych przez Magdalenę Danielewiczową (Danielewiczowa 2010), brak możliwości przekształcenia narzędnika na zdanie podrzędne, byłby dowodem na to, że pozycja czymś jest konotowana. W przypadku narzędnika przy czasowniku zapracować możliwość przekształcenia jak najbardziej istnieje, por.:

20 Takie konteksty jak Jak zapracować na szczęście? czy Jak zapracować na zaufanie? Jak zapracować na sukces?, które zdają się zastępować czym, podsuwają swą formą podejrzenie, że chodzi nie o przyczynę, nie o narzędzie, lecz o sposób. To także - moim zdaniem - nie jest poprawne rozpoznanie. 
(33) Na przyjazny gest Malediwów zapracował tym, że wykazał się talentem dyplomatycznym.

(34) Na swoje osiągnięcia zapracowała w ten sposób, że wykorzystała talent i ciężko, sumiennie pracowała.

(35) Na stypendia burmistrza uczniowie zapracowali tym, że osiągnęli dobre wyniki $\mathrm{w}$ nauce i sporcie.

(36) Na pominięcie w dyskusji zapracował sobie tym, że lekceważył problem.

Dokonane powyżej przekształcenia nie mogą jednak posłużyć za argument rozstrzygający o odrzuceniu tej pozycji jako niekonotowanej, choćby dlatego, że w polszczyźnie nietrudno wskazać czasowniki, wymagające uzupełnienia o zdania podrzędne (np. Wiedział, że wyjechałam. Wiedział o moim wyjeździe). Ponadto - jak widać w przykładach (33)-(36) - istnieje możliwość przekształceń narzędnika do różnych typów zdań podrzędnych, co z kolei mogłoby sugerować różne funkcje pozycji czymś. Test ten nie daje zatem odpowiedzi, czy omawiana pozycja jest przy czasowniku zapracować konotowana. Co więcej, równie zwodnicze byłoby zastosowanie testu redukcji, ponieważ odbieranie przykładów jako kompletnych czy niekompletnych jest z jednej strony silnie powiązane z szykiem (i strukturą tematyczno-rematyczną), z drugiej - zależne od kompetencji językowej testującego. To dlatego zdanie:

(37) Na stypendia burmistrza uczniowie zapracowali.

- wydaje się albo niekompletne, albo sugeruje, że ktoś wcześniej podważał zasadność przyznania uczniom stypendiów. Wystarczy jednak zmienić szyk (a przede wszystkim strukturę tematyczno-rematyczną i związane z nią akcentowanie elementów wypowiedzi) a zdania nie będą wydawały się niepełne. Na przykład:

(38) Uczniowie zapracowali na stypendia burmistrza.

Tyle tylko, że przy tak zmienionym szyku skłonni jesteśmy przyjąć, że uczniowie zdobyli stypendia, ponieważ wyróżniali się na tle innych osób, będących uczniami, innymi słowy - że zrobili dostatecznie dużo rzeczy, które zwykle robią uczniowie, by otrzymać stypendium. Zatem i test redukcji nie daje jednoznacznej odpowiedzi, choć minimalnie przechyla szalę na rzecz konotowania pozycji narzędnikowej.

Inny z testów stosowanych niekiedy w celu zweryfikowania, czy pozycja jest konotowana, czy nie, zakłada, że o wszystkie pozycje niezrealizowane w wypowiedzi można nadawcę danego komunikatu dopytać, ale tylko na pytanie o informacje wskazywane w pozycjach niekonotowanych może paść odpowiedź: Nie wiem. Zastosowanie tego testu do przywołanych wyżej przykładów także nie prowadzi do jednoznacznej konkluzji, że pozycja czymś przy czasowniku zapracować1 jest konotowana. Por. osobliwość dialogu: 
(39) - Uczniowie zapracowali na stypendia.

- Czym?

- 'Nie wiem. (ale: Nie wiem. Ich wychowawca tak mi powiedział.)

Dialog taki nie budziłby wątpliwości tylko w sytuacji, gdyby pierwszy z mówiących relacjonował czyjąś (a nie własną) opinię, bądź gdyby obaj rozmówcy znali uczniów, o których rozmawiają, na tyle, by wiedzieć, że nie zasługują oni na stypendia.

Bardziej jednoznacznie wypada powyższy test dla czasownika zapracować2, por::

(40) - Zapracował na pominięcie go w dyskusji.

- Czym?

$-{ }^{\star}$ Nie wiem.

Mimo braku jednoznacznego potwierdzenia, że narzędnik jest konotowany przez zapracowaćl, skłonna jestem uważać tę pozycję za wynikającą z treści omawianego czasownika. Argumentem pośrednim przemawiającym za takim rozwiązaniem byłyby konteksty, które w USJP zostały odnotowane jako osobne znaczenia (zapracować2). Z naszej wiedzy o świecie wynika, że na awans w pracy zapracować można, wykonując swoje obowiązki wzorowo, na stypendium uczeń czy student zapracować może wynikami w nauce lub osiągnięciami sportowymi, na dom zapracować można podejmując pracę zarobkową. Są to relacje oczywiste, stąd tendencja do dostrzegania w treściach, które pojawiają się w pozycji czymś, przyczyny i w konsekwencji brak wynikania pozycji czymś ze znaczenia czasownika. Jeśli jednak na pozycję czymś spojrzymy z perspektywy zapracować2, okaże się, że treści narzędnikowe regularnie bywają nieoczywiste. Na osamotnienie można zapracować albo nad wyraz gorliwie wykonując obowiązki zawodowe, kiedy nie starcza czasu na nic innego, albo opryskliwością, albo rozpowszechnianiem plotek, albo innymi sposobami, które są szczególne, niepowtarzalne i wymagają tego, by wskazać je wprost. Dlatego skłaniam się ku temu, by uznać pozycję czymś za konotowana przez oba czasowniki, lecz bardzo nieregularnie realizowana przy zapracować1.

Pozostaje jedno jeszcze pytanie związane z pozycją czymś, mianowicie - czy jest to pozycja przeznaczona na narzędzie czy na przyczynę? Ponieważ obiekt jest zdarzeniowy, jako pierwsza nasuwa się interpretacja przyczynowa omawianej pozycji. Tymczasem przyczynę wykluczyłabym z kilku powodów. Po pierwsze, dlatego że nie da się wprowadzić jej do zdania w najbardziej typowy sposób. $\mathrm{W}$ wyniku takiego zabiegu powstaną zdania nieakceptowalne ${ }^{21}$, por.:

${ }^{21}$ Nieakceptowalność nie wynika w tym przypadku ze zmiany formy gramatycznej, lecz ze znaczenia. 
(41) ${ }^{\star}$ Na swoje osamotnienie zapracował z powodu opryskliwości.

(42) ${ }^{\star} \mathrm{Na}$ swoje osiągnięcia zapracowała $\mathrm{z}$ powodu talentu.

Fraza wprowadzająca przyczynę nie łączy się pod względem znaczenia z omawianym czasownikiem. Po drugie, co zapewne wpływa na brak akceptowalności dwu ostatnich przykładów, pozycja obiektu zdarzeniowego wprowadzanego biernikiem ukrywa już skutek pewnych działań. Dlatego w pozycji narzędnikowej widzę miejsce na treści, które wskazują na środek, po który sięga się, by spowodować, aby możliwe stało się osiągnięcie tego, co wskazane w pozycji na coś. Pozycję czymś uważam zatem za przeznaczoną na narzędzie, aczkolwiek raczej narzędzie nietypowe.

\section{Podsumowanie}

Rozważania nad właściwościami składniowymi czasownika zapracować, pozwalają na przedstawienie kilku hipotez, które wymagają dalszej refleksji. Przede wszystkim, zaprezentowane interpretacje pozwalają przyjąć, że wskazywać należy istnienie dwu jednostek opartych na kształcie zapracować, mianowicie: ktoś zapracowat na coś (czymś) oraz ktoś zapracowat (sobie) na coś czymś. Jednostki te, różniąc się znaczeniem, wchodzą w relacje semantyczne z odmiennymi wyrażeniami. Na tym etapie można twierdzić, że zapracować1 pozostaje słowotwórczo (formalnie i znaczeniowo) powiązane z czasownikiem pracować (a dokładniej ktoś pracuje na coś czymś); natomiast zapracować2 ze względu na znaczenie powiązane jest bezpośrednio z czasownikiem robić, ze wspomnianym czasownikiem pracować łączy się ze względu na podobieństwo formalne.

Czasownik zapracować1 różni się od zapracować2 treściami pojawiającymi się $\mathrm{w}$ pozycji przeznaczonej na obiekt zdarzeniowy ( $\mathrm{i}-\mathrm{w}$ mniejszym stopniu - charakterystyką agensa). W konsekwencji agens występujący przy zapracować1 może odnosić bezpośrednie lub pośrednie korzyści ze swoich działań, natomiast agens, który pojawia się przy zapracować2 doświadcza zmiany swego położenia na gorsze, ponieważ podejmował działania na swoją niekorzyść.

Nie można wykluczyć, że różnice w otwieranych pozycjach składniowych dotyczą przede wszystkim płaszczyzny treści, a nie różnic w ilości i jakości otwieranych miejsc, ponieważ neosemantyzacja zapracować i wyodrębnianie zapracować2 dopiero się dokonuje. 


\title{
Bibliografia
}

Buttler, D. (1976). Innowacje składniowe współczesnej polszczyzny. Walencja wyrazów. Warszawa: PWN.

Danielewiczowa, M. (2010). Schematy zdaniowe - podstawowe kwestie metodologiczne, Poradnik Językowy z. 1, 27-34.

Danielewiczowa, M. (2018). Strukturalne i semantyczne uwarunkowania walencji przymiotników (na materiale polskim), Prace Filologiczne, LXXII, 13-29.

Dróżdż-Łuszczyk, K. (2011). Człowiek się rodzi na pracę, a ptak na latanie. Semantyczno-składniowe a kontekstowe właściwości leksemu PRACOWAĆ, Poradnik Językowy Z. 1, 43-52.

GWJP - Gramatyka współczesnego języka polskiego. Morfologia t. 2, (red.) R. Grzegorczykowa, R. Laskowski, H. Wróbel, Warszawa 1999: PWN.

Szupryczyńska, M. (1996). Pozycja składniowa frazy celownikowej w zdaniu polskim, Toruń, Top Kurier.

Zaron, Z. (2009). Problemy składni funkcjonalnej. Warszawa: Bel Studio.

\section{Słowniki}

ISJP - Inny słownik języka polskiego, t.2, (red.) M. Bańko, Warszawa 2000;

USJP - Uniwersalny słownik języka polskiego, t. 4, (red.). S. Dubisz, Warszawa 2008;

WSJP - Wielki słownik języka polskiego, (red.) P. Żmigrodzki, https://wsjp.pl/

\begin{abstract}
ABSTRAKT: Artykuł poświęcony jest analizie składniowej polskiego czasownika $z a-$ pracować. Punktem wyjścia dla rozważań jest obserwacja, że walencja czasownika często bywa - niesłusznie - ograniczona do opisu formalnego. Autorka artykułu skupia się na charakterystyce semantycznej, która jej zdaniem jest równie istotna. Autorka podejmuje próbę skonfrontowania walencji czasowników zapracować i pracować. Przedstawia propozycję, w której czasownik zapracować otwiera trzy pozycje, i dla każdej z nich przybliża charakterystykę semantyczną.
\end{abstract}

